\title{
Service Products and Brand Determination Strategy
}

Mendeca Liloca ${ }^{1}$, Simone Stewart ${ }^{1}$

${ }^{1}$ Department of Economy, University of Eduardo Mondlane, Mozambique

*Corresponding Author: Mendeca Liloca

Received: October 28, 2020

Revised: November 12, 2020

Accepted: November 18, 2020

\begin{abstract}
This study purpose to understand the service products and brand determination sttrategy This study discusses products and services, classification of products and services, brand determination strategy and marketing services. Choosing a brand name involves finding the best brand name based on a careful review of the benefits of the product, the target market, and the proposed marketing strategy. service marketing that need to be known in service marketing, namely: Intangibillty, Inseparability, Variabillity/heterogeneity.
\end{abstract}

Keywords: Determination Strategy, Marketing Service, Service Products

\section{Introduction}

A product is anything that can be offered to the market in order to attract attention, acquisition, use, or consumption that can satisfy a desire or need. Service is a form that consists of activities, benefits, or satisfaction offered for sale and is basically intangible and does not result in ownership of something (Al-Marri et al. 2007). producers in marketing their products or services must require consumers about the products or services they produce. One of the methods used by producers in marketing for the purpose of increasing revenue is through brands, while a product will not be purchased if the product is unknown. So determining a good brand also affects the marketing of a product. A well-known brand will sell well even though there are other products with the same quality in circulation. It is undeniable that product branding is one of the factors necessary for the success and marketing strategy adopted by a company, especially at this time when the information age is growing rapidly, so branding is one of the most powerful weapons for companies in developing and maintaining a business.

Therefore, it is imperative for companies to carry out branding with the right strategy in order to meet effective targets. The marking that is carried out must be in accordance with the circumstances of the company. As it is known, the state of the business world is dynamic, which always changes at any time and there is a relationship between one another. Therefore, the branding strategy has a very important role for the success of the company in general and in the marketing sector in particular. In addition, the marketing strategy applied must be reviewed and developed in accordance with market developments and the market environment. Thus the marketing strategy must be able to provide a clear and directed picture of what the company does in using every opportunity or a combination of several target markets. 


\section{Defining Products and Services}

According to Smith, (1956). products are goods or services that can be bought and sold. In marketing, a product is anything that can be offered to a market and can satisfy a want or need...At the retail level, products are often referred to as merchandise. In manufacturing, products are purchased in the form of raw goods and sold as finished goods. Products in the form of raw materials such as metals or agricultural products are often referred to as commodities. The word product comes from the English product which means "something produced by labor or the like". The working form of the word product, produce, is an uptake from the Latin prōdūce (re), which means (to) lead or bring something forward. In 1575, the word "product" refers to anything that is produced ("anything produced"). However, since 1695, the definition of the word product refers to something that is produced ("thing or things produced").According to Stiglitz, (1998) Products in the economic sense were first introduced by the economist-politician In broader usage, products can refer to a single good or unit, a group of the same products, a group of goods and services, or an industrial grouping of goods and services.

In a broad definition, a product is anything that can be offered to the market for attraction, acquisition, use, or consumption that can satisfy a want or need. Products include not only physical objects but also services, events, people, places, organizations, ideas, or a mixture of these entities Kavaratzis, (2005). Services are products that consist of activities, benefits, or satisfaction that are sold and are essentially intangible, such as banking, hotels, tax planning, and home improvement services.

Product planning should think about products and services at three levels. The rate adds more customer value. The most basic level is the core benefit, which raises the question What do buyers really buy? When designing products, marketers must first define the core, problem-solving benefits or services that consumers are looking for. A woman who buys lipstick buys more than just lip color. Charles Revson of Revlon saw this already: "In the factory, we make cosmetics. In the shop we sell hope." And people buying blackberries are buying more than cordless cell phones, e-mail and web browsing equipment, or personal agendas. They buy freedom and direct relationships with other people and resources.

At the second level, Alonso-Rasgado,. According to Alonso-Rasgado (2004) product planners must convert the core benefits into actual products. They must develop product and service features, design, quality level, brand name and packaging. For example, BlackBerry is an actual product. The names, components, styles, features, packaging and other attributes have all been carefully combined to deliver the core benefits of staying connected.

Finally, the product planner must build the incremental product around the core benefit and the actual product by offering additional customer services and benefits. BlackBerry must offer more than just a means of communication. BlackBerry must provide a complete solution to high mobility connectivity issues. Therefore, when a customer purchases a BlackBerry, the company and its distributors may also provide warranties about parts and workmanship, instructions on how to use the equipment, prompt repair service when needed, and a toll-free telephone number and website to use if they have a problem or question.

\section{DOI:}

Copyright@2020,JournalDimensieManagementandPublicSector, Underthelicense CC BY-SA 4.0 | 13 
Consumers see a product as a complex collection of benefits that satisfy their needs. When developing a product, marketers must first identify the core customer needs that a product will satisfy. Then marketers have to design the actual product and find ways to add to that product in order to create the set of benefits that will provide the most satisfying customer experience.

\section{Main Classification of Products and Services}

Products and services are divided into two major groups based on the type of consumers who use them, namely consumer products and industrial products. Lian \& (2008). (1) Consumer products are products and services purchased by end consumers for personal consumption. Marketers usually classify these products and services further based on how consumers buy them. Consumer products include:(a) Products of daily necessities (convenience products) are consumer products and services that are usually purchased frequently and promptly by customers, with minimal comparison and purchase efforts. (b) Shopping products are consumer products and services that are purchased less frequently and customers carefully compare product suitability, quality, price and style. (c) A specially made product is a consumer product and service with unique characteristics or brand identification in which a significant group of buyers is willing to undertake a special purchasing business. (d) An unsought product is a consumer product that may not be known to consumers or a product that consumers may know but usually consumers do not think about buying. (2) Industrial products are products that are purchased for further processing or for use in conducting a business

The difference between consumer products and industrial products is based on the purpose for which the product is purchased. Von Hippel (1978).

\section{Brand Determination Strategy}

Some analysts view the brand as the company's main marketing asset. A brand is more than just a name and a brand symbol to form everything a product or service means to consumers. Brand equity is the positive differential effect that knowing the brand name will make the customer respond to the product or service. Brands with strong brand equity are very valuable assets. In building brands, companies must make decisions about brand postioning, brand name selection, brand sponsorship, and brand developmentvan Mesdag (1997)The strongest brand positioning creates strong consumer trust and value. Choosing a brand name involves finding the best brand name based on a careful review of the benefits of the product, the target market, and the proposed marketing strategy. Manufacturers have four choices of brand sponsorship, namely the manufacturer can launch the producer brand (or national brand), sell to intermediary sellers who use private brands, market licensed brands, or combine other strengths to co-brand the product.

The company also has four choices when the company develops its brand. Companies can introduce line extensions, brand extensions, multiple brands, or new brands. Companies must build and manage their brands with care. Brand positioning must be continuously communicated with consumers. Advertising can help. However, brands are not raised by advertising but by brand experience. Customers know a brand through a wide range of relationships and interactions. Companies should pay much attention to managing these DOI: 
touch points as companies do when creating their advertisements. Therefore, the management of company brand assets cannot be left only to the brand manager. Now several companies are forming brand asset management teams to manage their main brands. Companies must regularly audit their brand strengths and weaknesses. Brands may need to be repositioned if there is a change in customer preferences or a new competitor. (1) Brand Equity, (2) Marking (3) Packaging (4) Labeling.

\section{Marketing Services}

Service characteristics are determined by four key characteristics, namely intangibility, inseparability, variability, and perishability. Wolak (1998). Each characteristic has problems and marketing requirements. Marketers are trying to find ways to make services more tangible, increase the productivity of providers that are inseparable from their products, set quality standards to deal with variability, and increase the movement of demand and supply capacity to deal with service loss. Good service companies focus on customers and employees. Service firms understand the service profit chain, which links service company profits to employees and customer satisfaction (Heskett et al 1994). A service marketing strategy requires not only external marketing but also internal marketing to motivate employees and interactive marketing to create service delivery expertise among service providers. To be successful, service marketers must create competitive differentiation, offer high service quality, and find ways to increase service productivity.

\section{Service Marketing Characteristics}

According Accordung to Vargo et al. (2004). there are four characteristics of service marketing that need to be known in service marketing, namely: Intangibillty (intangible), Inseparability (cannot be separated), Variabillity / heterogeneity (changeable), Perishabbility (not durable). Services cannot be stored and therefore cannot be sold in the future. In this case, services are different from goods, because usually goods can be stored and used over and over again, this is not the case with services, if services are not directly used, the services will just pass away. A service provided by a service provider depends on changing market demands.

\section{Conclusion}

Products are a key element in a market offering, marketing begins with formulating an offer that delivers value to the target customer. To differentiate an offering in addition to just making a product they also offer a service, they create and manage customer experiences with the product or company. Companies that market experience realize that customers are actually buying more than just products and services. characteristics of service marketing that need to be known in service marketing, namely: Intangibillty (intangible), Inseparability (cannot be separated), Variabillity / heterogeneity (changeable), Perishabbility (not durable)

\section{References}


Al-Marri, K., Ahmed, A. M. M. B., \& Zairi, M. (2007). Excellence in service: an empirical study of the UAE banking sector. International Journal of Quality \& Reliability Management.

Heskett, J. L., Jones, T. O., Loveman, G. W., Sasser, W. E., \& Schlesinger, L. A. (1994). Putting the service-profit chain to work. Harvard business review, 72(2), 164-174.

Kavaratzis, M. (2005). Place branding: A review of trends and conceptual models. The marketing review, 5(4), 329-342.

Lian, J. W., \& Lin, T. M. (2008). Effects of consumer characteristics on their acceptance of online shopping: Comparisons among different product types. Computers in human behavior, 24(1), 48-65.

Stiglitz, J. E. (1998, April). Knowledge for development: Economic science, economic policy, and economic advice. In Annual World Bank conference on development economics (Vol. 20, pp. 9-58). Washington: World Bank.

Smith, W. R. (1956). Product differentiation and market segmentation as alternative marketing strategies. Journal of marketing, 21(1), 3-8

Thompson, G., \& Elfström, B. O. (2004). The design of functional (total care) products. Journal of engineering design, 15(6), 515-540

Von Hippel, E. (1978). Successful Industrial Products from Customer Ideas: Presentation of a new customer-active paradigm with evidence and implications. Journal of marketing, 42(1), 39-49.

Vargo, S. L., \& Lusch, R. F. (2004). The four service marketing myths: remnants of a goodsbased, manufacturing model. Journal of service research, 6(4), 324-335.

van Mesdag, M. (1997). Brand strategy needs turning back to front. Marketing Intelligence \& Planning.

Wolak, R., Kalafatis, S., \& Harris, P. (1998). An investigation into four characteristics of services. Journal of Empirical Generalisations in Marketing Science, 3(2). 